\title{
MAKING A TOURISM ICON: THE VALORIZATION OF SITI NURBAYA BRIDGE IN WEST SUMATERA
}

\author{
Deni Endriani \\ Email: endriani.deni@ehess.fr
}

\begin{abstract}
This article discusses about Siti Nurbaya Bridge in Padang, West Sumatera, which is considered to have potency to be expanded into a tourism icon. By being an attractive tourism object, this awesome place could give some benefits for local people as well as the government. This article is focused on the bridge and the visitors, the weaknesses and strenghts of the attraction, and how the weaknesses can be reduced to create a more attractive, enjoyable, and beneficial tourism object in Padang. The data was collected trough observations, interviews, and literary studies. It is found that there are two options offered in order to develop and valorize the tourism value of the bridge. They are creating a culinary night market and holding a traditional art performance called Randai.
\end{abstract}

Key words: Siti Nurbaya Bridge, culinary night market, randai, valorization

\section{Introduction}

The objective of this writing is to describe Siti Nurbaya Bridge as one of tourism attractions in Padang, West Sumatera, after being built for 12 years. Then, in order to improve its value as well as its quality, it is important to analyze the possibility to combine the Siti Nurbaya Bridge and Minangkabau culture through a performance, for instance Randai.

\section{Tourism and Culture}

Tourism and Culture are placed under different departement or mininstry in Indonesian governmental instution. ${ }^{1}$ In current cabinet, The Working

1 In the government of President Soeharto for 32 years named Kabinet Pembangunan I until VII, the culture was under the Department of Education and Culture, meanwhile tourism just arose in Kabinet Pembangunan IV under the Ministry of Tourism, Post and Telecomunication, and then was changed into the Department of Tourism, Art, and Culture in Kabinet Pembangunan VII.

In the government of President Abdurrahman Wahid (26 Oktober 1999 - 9 Agustus 2001), Kabinet Persatuan Nasional, the tourism was under the ministry of tourism and art.In the government of President Megawati Soekarno Puteri (9 August 2001 - 9 August 2004), Kabinet Gotong Royong, Culture and Tourism were in the same ministries. In the government of President SBY, Kabinet Indonesia bersatu I (20042009), Ministry of Cultural and Tourism was led by Minister JeroWacik. 
Cabinet (Kabinet Kerja), leaded by President Joko Widodo, tourism affairs are placed under The Ministry of Tourism, while Culture affairs are under the Ministry of Culture and Elementary \& Secondary Education. ${ }^{2}$ It is quite different from the former cabinet, Second United Indonesia Cabinet (Kabinet Indonesia Bersatu Jilid II), leaded By Susilo Bambang Yudoyono who placed culture affairs under The Ministry of Education and Culture and Tourism was under The Ministry of Tourism and Creative Economy.

The national development of tourism side along 2010-2025 is focussed on the development of tourism destination, marketing, tourism industries and institutional, meanwhile the national development of culture is focussed on cultural rights, development of national identity and characteristic, cultural diplomacy, human resource and cultural pranata, and the development of cultural facilities and infrastructure. Tourism attraction, as one of cultural destination components, is determined as "everything which has the unique, beauty, and value of variety in natural, cultural, and homemade products to be the object of tourism". This is where the root of relationship between cultural and tourism is started.

Tourism and cultural are two different things which can be related, walk along side by side, and completely match one to another. A reason to do travelling is to enjoy a culture of particular place and its society. Urry (in Richard, 2001:4) states that tourism is a culture. Observing the tourism development in Bali, as an example, the tourism itself could give a very huge benefit to the citizen to love their culture more than they did before (Picard, 2004). Aside the impact given by this activity, the Balinese keeps living by applying the culture which has been there previously by years.

Problems that arise due to the separation of the management of tourism and culture in West Sumatra is quite reasonable. ${ }^{3}$ Herwandi (2014) states that the renovation of culural sites which is held by the government in order to serve cultural object is a wrong interpretation to the culture. Visiting a site or historical place is just an ancient way in interpreting a culture, so that the understanding of tourism is getting narrowed (Richards, 2001).

In Kabinet Indonesia Bersatu II (2009-2014), Marie Elka Pangestu was chosen as the minister of tourism and economy creative (19 Oktober - 27 Oktober 2014), before a reshuffle called Ministry of Cultural and Tourism (22 Oktober - 19 Oktober 2011) whereas Jero Wacik as the minister. Meanwhile, the minister of education and culture was led by Muhammad Nuh.

2 Kabinet Kerja President Joko Widodo - Jusuf Kalla in period 2014 - 2019

3 Read Herwandi (2014): Separate the Management of Tourism: It Is the Time to Establish Department of Cultural Affairs; Sudarmoko: Separate the Management of Tourism: Firstly Change the Understanding of Culture; Alfian Jamrah: Seperate the Management of Tourism: Cultural matter is an obligation. Herwandi states that there are five reasons to separate the management of both two sides, those are: (1) Setting a culture as an asset to support tourism, (2) the representatives who are competiting to create a new cultural product which has actually run out from its natural characteristics, (3) the way of thinking owned by the representatives in cultural and tourism that considers the tourists might always tend to think "glamour and excesses are always attracting" and always deals with western culture, (4) there were some renewed historical and cultural object, and some tourism attractions were built in the middle of historical and cultural sites in order to make it to be more glamorous, (5) Disobeying special purposes of cultural inheritance as a way to keep the national characteristics. 


\section{Siti Nurbaya Bridge}

The bridge is located in Bukik Gado-gado village, Padang Selatan subdistrict, connecting Batang Harau and Bukik Gado-gado village (Bukik Suntiang). It is 60 meters long, was built in 2002, and spent 20 billions Rupiah in the reign of Governor Zainal Bakar. It lies above Batang Harau River, a port for the fishermen's boats, ships and yachts. In the beginning of $19^{\text {th }}$ century, Batang Harau had been a city of port and trading after the establishment of warehouse which was created by Dutch Trading Company (VOC) in Padang (Photo 1).

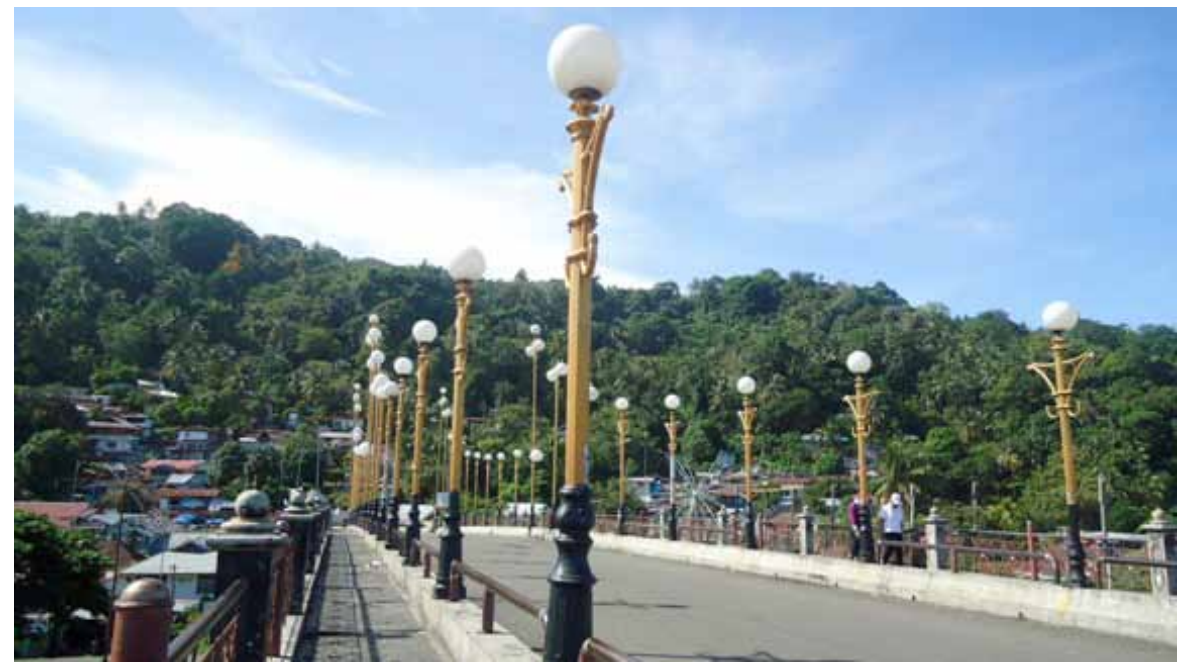

Photo 1. Siti Nurbaya Bridge in the days (Personal collection)

This bridge was named "Siti Nurbaya" in order to remind us about the the story of Siti Nurbaya, one of Minangkabau folk tales. Siti Nurbaya (Kasiah tah Sampai) was also the title of a well known novel written by Marah Rusli in 1920 (Photo 2)

Why is Bukik Gado-gado or Bukik Suntiang interesting? This area was known as china town because there were a lot of Chinese's graveyards, and it was as an access from Padang to Muaro Beach. In the Batang Harau village, there is Padang Mountain, where the graveyard of legendary Siti Nurbaya was found, and Lobang Jepang as the heritance of Japanese soldiers. Besides, along the outfall of Batang Harau River there are some ancient buildings left by the Dutch colonialism to be known as China Town (Kota Tua). It is a land of Tionghoa Chinese' ethnics. See figure 3.

The attractions in the days and nights are definitely different. In the day, the natural beauty of Padang mountain can be seen clearly, the buildings of Kota Tua, the ships and boats lining on the edge of the river which ends 


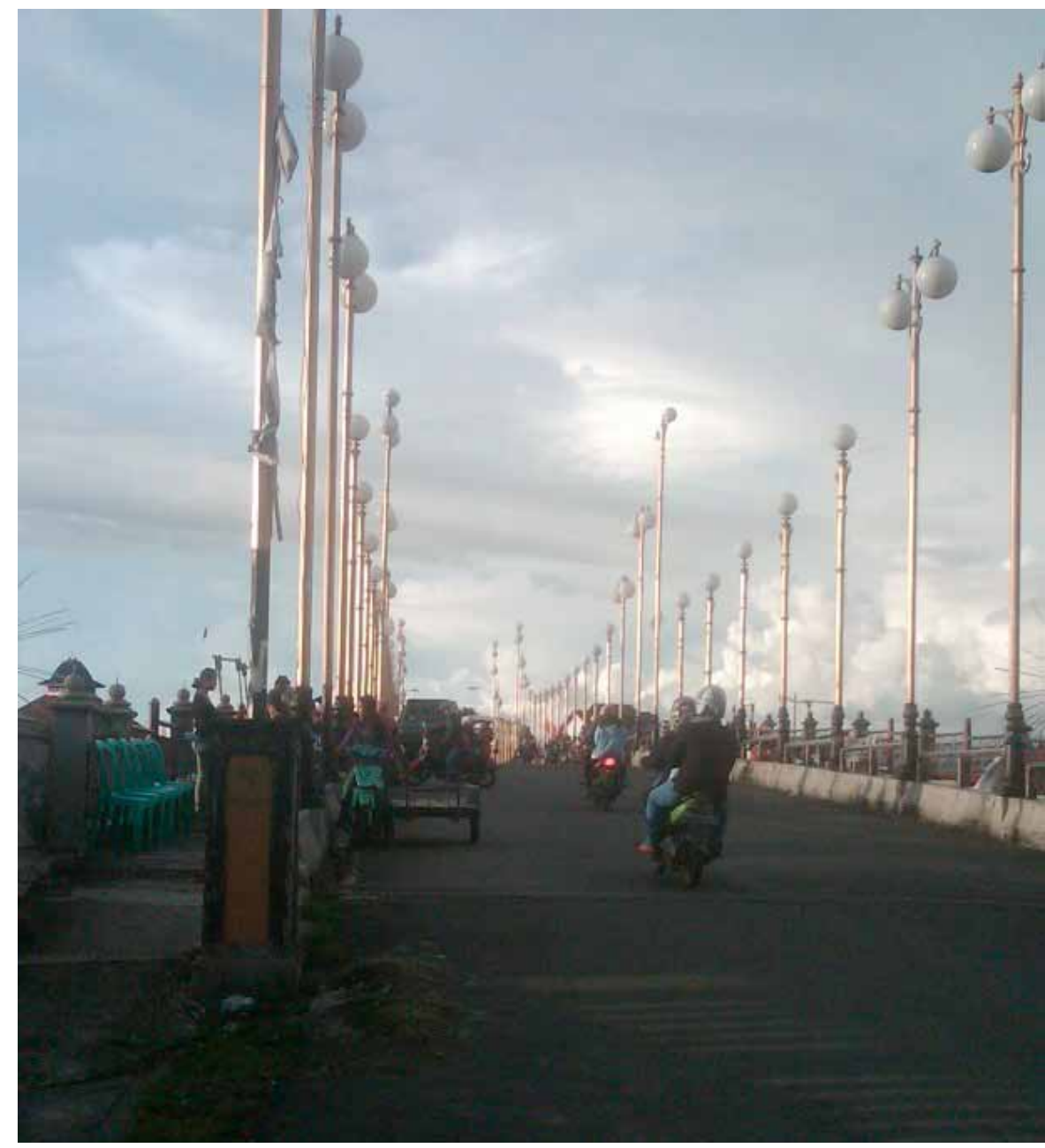

Photo 2. Siti Nurbaya Bridge in the days (Personal collection)

in Hindia Ocean, as well as the well-organized traffic. While in the nights, street's lights along the bridge start to light up the area sharpen its beauty at nights. The vendors on the sidewalks provide food, and set the table and chairs very well to serve the visitors. They have special menu, such as grilled corn, grilled banana, cold soda and traditional warm drinks. The visitors are not only from Padang, but also from other city, in and out of Indonesia. They could be teenagers, or maybe families who want to spend time together.

Based on the observations and interviews result, it can be concluded that there are about 50 vendors selling food and beverage on the Siti Nurbaya Bridge. They are mostly women in productive ages. They all come from Batang Harau village because the local people from other area are not allowed to sell over there in avoiding fights due to competition. They start working from 5 to 


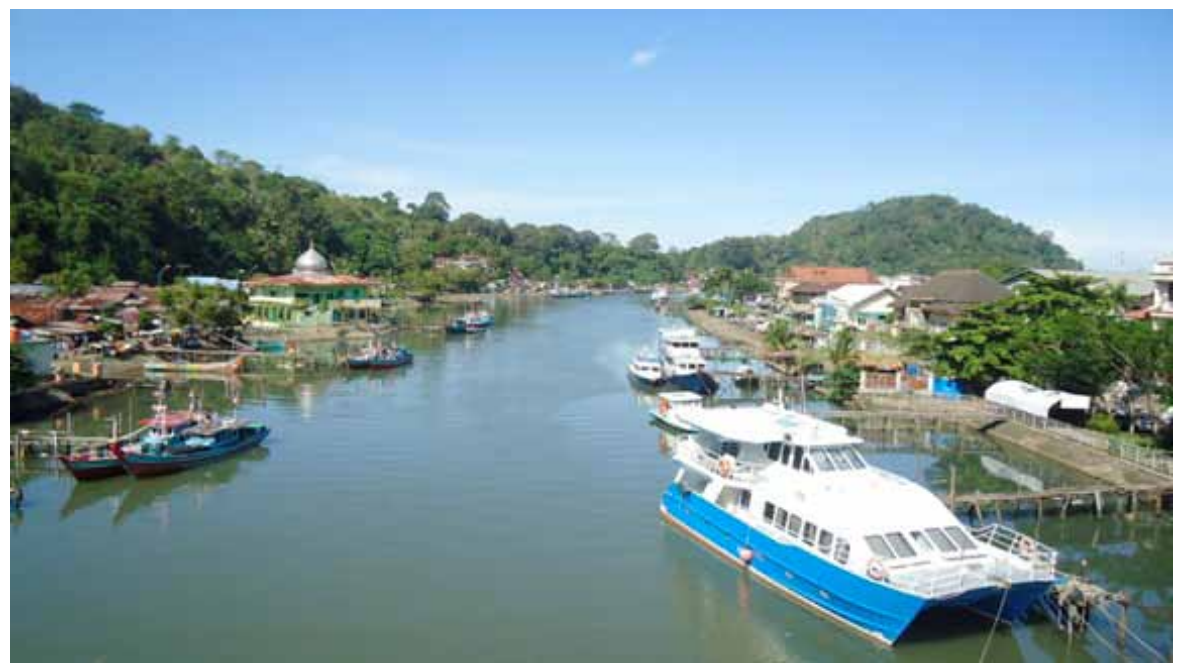

Photo 3. The view alongside of Batang Harau River (personal collection)

10 p.m., while on the weekend they open until 11 p.m or even midnight. Their reasons for selling are the demands in terms of economic problems as well as taking the benefit of their free time (See Photo 4).

Let's analyze the motivations of the visitors. E, 46 years old, visits Siti Nurbaya bridge with her family for leisure, enjoying the beauty of nature around the bridge and also enjoying the traditional food while kidding with other family members. This bridge is a symbol of the meeting place between Siti Nurbaya and her lover, Syamsul Bahri, which becomes a legend till nowadays. They usually meet on the day and at night, especially on Sunday. On the day, this place has its own attraction, without the vendors on the sidewalks, the views of the river and Kota Tua can be seen clearly. On the contrary to these the situation, the vendors are a little bit over crowded at night. They make the beautiful brigde become a little bit messy because their unorganized boothes. They need to be organized very well in quantity as well as quality, so that the bridge will be much better. Moreover, the existence of the youth (usually students) who always spend time together or dating gives a bad impression for the other visitors, especially at night.

Another visitor, R, 24 years old, visits this place in the morning and at night. In the morning, he enjoys the views to calm his mind. On the other hand, the management among the vendors is not organized very well, and there is an illegal extortion for security and troubadours.

S, 24 years old, also visits this place on the day and night because of its unique attraction. The reasons why he comes are; to enjoy the panoramic views, to spend the time to do his hobby in photography, and also to have culinary tours. Unfortunately, the visitors cannot stand freely on the 


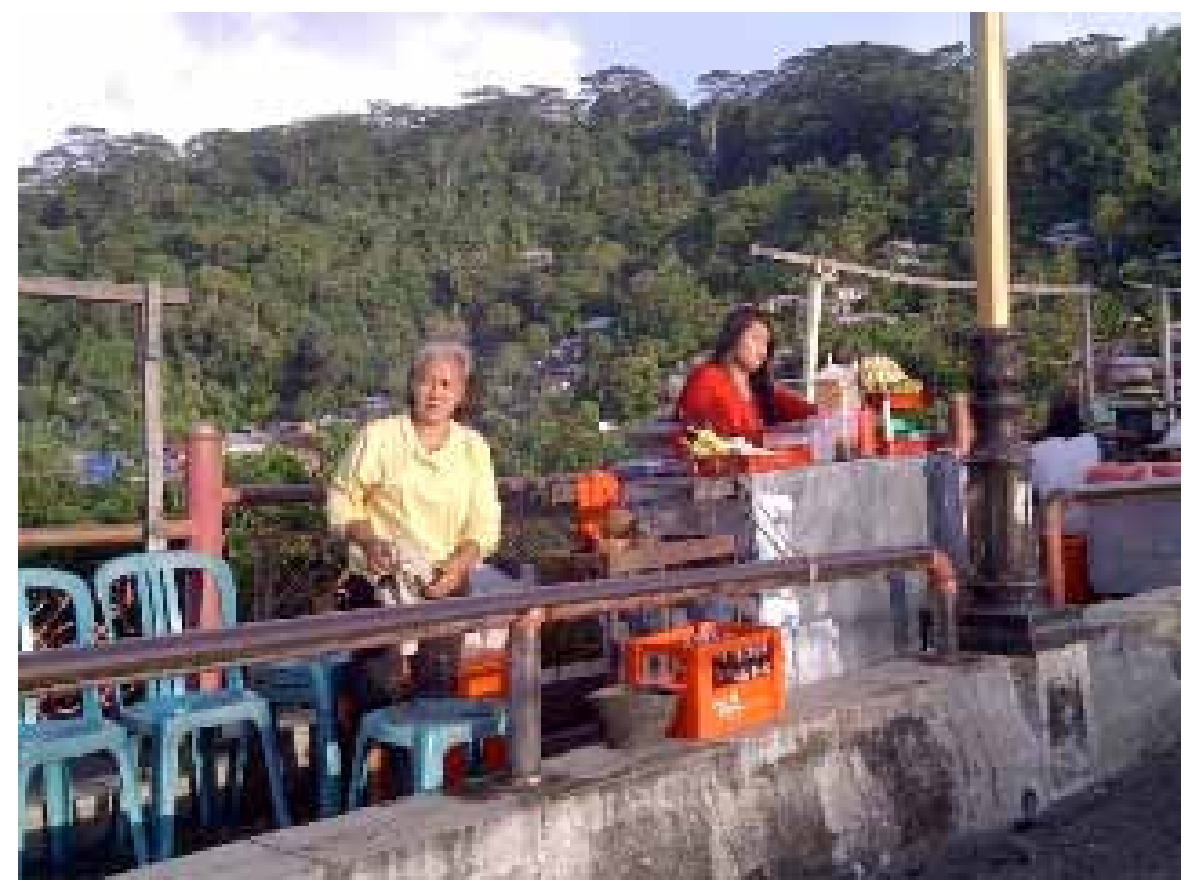

Photo 4. The vendors in Siti Nurbaya Bridge (Photo by Rudi)

sidewalks because it has been taken by the vendors'stuffs. The only way out to be on the sidewalks is to buy something form them. The troubadours and the beggars always come over repeatedly, parking area that takes the road and the views from the youth who just selfishly do impolite attitude in front of many people.

A, 23 years old, who visits on the day and night. The existence of the vendors at night impresses a circumstance that being less clean, disorganized trash derived from the food they sell, and the arising of traffic jam. S, 18 years old, usually visits this place with her family in the evenings. She wants to see a wonderful sunset and panoramic views. She states that the negative sides are the vendors who take quite large space of the road for selling, the troubadours and beggars who always come over, the unclear parking free, and the annoying youth surround them. ${ }^{4}$

Furthermore, let's examine the correspondents' responds about Siti Nurbaya Bridge, as mentioned below:

According to some travel agent in Padang, ${ }^{5}$ visiting Siti Nurbaya Bridge is one of regular itinerary. The tourists could enjoy the food sold by the vendors, enjoy the views of Old China Town, Padang mountain, and then continue to shop for some souvenirs such as traditional food in Casava crackers "kerupuk

4 The writer just write the initial of the visitors

5 The interview from Internet 


\begin{tabular}{|c|c|}
\hline Positive Responses & Negative Responses \\
\hline $\begin{array}{l}\text { - Enjoying the beauty and serenity of } \\
\text { China Town along the side of Batang } \\
\text { Harau River, the houses at the foot of } \\
\text { Padang Mountain. }\end{array}$ & $\begin{array}{l}\text { - The vendor are numerous and unorga- } \\
\text { nized. They cause the lack of space for } \\
\text { visitors in exploring this place. }\end{array}$ \\
\hline $\begin{array}{l}\text { - The architectural of the bridge is won- } \\
\text { derful and attractive. }\end{array}$ & $\begin{array}{l}\text { - Improvement of public facilities is a } \\
\text { must. Inadequate the trash bin evoque } \\
\text { scattered garbage and bad smell. }\end{array}$ \\
\hline $\begin{array}{l}\text { - Siti Nurbaya legend is unforgettable } \\
\text { history. }\end{array}$ & $\begin{array}{l}\text { - The numerous unmarried young ages } \\
\text { that are dating stimulate uncomfort- } \\
\text { ability for the tourists. }\end{array}$ \\
\hline - A place for refreshing and rilexing & $\begin{array}{l}\text { - Pyshically, the bridge needs mainte- } \\
\text { nance because of insufficiency of the } \\
\text { lights, and the cleanness }\end{array}$ \\
\hline - An interesting photography spot & - The unofficial race in the nights \\
\hline - A leisure place for family & $\begin{array}{l}\text { - The troubadours and beggars come } \\
\text { and go, disturb the visitors and no one } \\
\text { control them }\end{array}$ \\
\hline $\begin{array}{l}\text { - Enjoying the Minangkabau traditional } \\
\text { culinary }\end{array}$ & - Parking area is not adequate \\
\hline $\begin{array}{l}\text { - Increasing the economic profit for local } \\
\text { people and a source of devisa for the } \\
\text { government }\end{array}$ & $\begin{array}{l}\text { - An illegal retribution for parking, and } \\
\text { an illegal extortion for security }\end{array}$ \\
\hline \multirow[t]{4}{*}{ - Enriching the tourism in Padang } & - The traffic jam at the nights \\
\hline & - Limited transportation acces \\
\hline & $\begin{array}{l}\text { - Static attraction without activity, only } \\
\text { the bridge for sitting and eating the } \\
\text { snacks }\end{array}$ \\
\hline & $\begin{array}{l}\text { - The anxiety of visitors toward the se- } \\
\text { curity }\end{array}$ \\
\hline
\end{tabular}

Table 1. The correspondents' responds about Siti Nurbaya Bridge

sanjai" outlet called Christine Hakim, which is quiet popular, on the end of the bridge.

By looking at the data reported, it can be concluded that the tourists are dominated by domestic visitors while the number of foreign visitors is very small. The lack of management toward the vendors reduces the value of tourist attraction in Siti Nurbaya Bridge. The sidewalks along the bridge are a public facility which is used carelessly by the vendors to sell their products. At night, the visitors could not stand directly on the edge of bridge to enjoy 
the panoramic of Batang Harau River because they have to defer to their status as costumers, in order to be allowed to sit and so that they could sit on the chairs provided by the vendors. They do not maintain the environmental cleanliness since it is easy to find the trash of their food everywhere nearby the location. The troubadours and beggars just come over to the visitors without any prohibitions.

In 2012, a domestic visitor and the writer visited Siti Nurbaya Bridge by car. After parking the car in front of a booth, they took a chair provided. Because there was a little bit high pole which can interfere his sight to the Panoramic Padang Mountain, China town, and Batang Harau river, they decided to move the left side. Unfortunatelly, the vendor who owned the chair got angry and chased us away as well as our car. She did so because the visitors were only allowed to park the vehicle right in front of the booth where they buy something. Because of it, $\mathrm{M}$ was so shocked and suddenly lost his appetite.

The government of Padang doesn't oblige them to pay for the Retribution or other compulsory fees. Otherwise, there is not any program held by the local government to improve their quality of service or a kind of hospitality training. Parking area for the visitors is also arranged by the seller with the provisions like; the customers may park in front of the foodstand itself and may not park in any other foodstands without buying anything.

The youth who like dating on the bridge show an inappropriate attitude to the visitors who come with family. The citizens in Padang, as Minangkabau people, have a strong customs, so that the youth who go dating before their marriage are considered as wrong, since it is not allowed by the common law of Minangkabau which based on the laws in Islam.

How to valorize the Siti Nurbaya Bridge? Richards and Wilkes (2008) stated "many attractions are physically incapable of operating commercially. Many museums and historic buildings will continue to require subsidy". They also suggested focusing on the marketplace and the market conditions. So the attraction of the Siti Nurbaya Bridge will not give the maximum profit and long supply chain. The writer offers two solutions in valorizing the value and increasing the function of Siti Nurbaya Bridge. They are by exposing this bridge as the center of culinary in term of a fair or night market, and holding an event such as Randai. To attract the visitors, it is needed an object of tourist attraction. Boniface and Cooper said that "attractions are the raison d'etre for tourism; they generate the visit, give rise to excursion circuits and create an industry of their own (in Leask, 2008:6)". Based on visitor classifications (Leask, 2008; Pearce, 2008 using the term of tourist site), Siti Nurbaya Bridge as a tourist attraction is a resource which was built in purpose, not a natural resource, so that it needs a maintenance management and improvement of the product quality. But, as one of public 
facility which is held by the country as stated in the constitution of 1945 , so that the maintanance is being controlled by the Janitor of the city itself, without the additional or even the specific one. Moreover, for the vendors who sell along the bridge, they have to be able to responsible for the cleanliness of that place as the replacement of retribution fee that should be withheld by the government.

\section{Siti Nurbaya Night Market}

Previously, let's see a night market in Kaohsiung, Taiwan and Pont des Arts in Paris, France, to see the tourism activities.

\section{a) Night Market in Kaohsiung, Taiwan}

The writter did the observation for less than three months in 2013 in Kaohsiung, Taiwan, which is the second big city after Taipei. Taiwan is a nation which consists of islands and really risky to earthquake, but still the development in all of the aspects grows rapidly, including in term of tourism. Night market is one of its tourism attractions. Some of the night market are ; Rui Feng, Guang Hua, Liuhe, Jin Zuan, Kaisyuan, Ling Ya, Zhong Xiao, Sing Jhong, Nan Hua, Ding Shan, Feng Shan, dan Wu Jia.

Visitors of the night market are not only its local people, but also domestic and foreign tourists. There can be found some food such as seafood, fruits, snacks from throughout the market; clothes and shoes; various games and souvenirs such as keychain and magnet which are relatively cheap and can be bargained.

The access to reach the night market is quite easy, either by bus or train MRT, and then the location is just nearby the transportation accesses. Crowded visitors, friendly traders, safe area, they all make the atmosphere becomes comfortable and festive. Even though the diversity in term of languages is very significant, that is Mandarin, but some traders can speak English. And the most important one there is no force to shop, so the visitors might be delighted.

\section{b) Pont des Arts in Paris}

It is about the charming of le pont des art in Paris. This bridge was built from 1801 to 1804 . It was built upon the initiative of Napoleon Bonaparte, with 11 meters breadth and 155 meters long. Since 1975, this bridge has been registered in the list of historical monument. Along the bridge, there are about 700.000 padlocks as the representative of love. This condition has been settled since 2008. The access to get in to the bridge can be reached by train metro, ${ }^{6}$ walking form the complex of Louvre Museum or the French institute building. From this bridge, there can be seen Eiffel Tower stand frimly on the riverbank of Seine River.

6 See the map of Paris Metro, http://ratp.fr 
The tradition of sticking the padlock can also be found in other tourism cities suah as London, New York, Seoul, Paris, and Taiwan. It is started in a city in Hungary, Pecs, in the beginning of $19^{\text {th }}$ century when the soldiers who live in a village left their padlock as well as the keys as keepsake.

While standing on the bridge, the visitors feel comfortable enjoying the natural beauty of the river and the panoramic of surroundings. The vendors are just in a very small number, perhaps just one or two of them offering mineral water or padlock, but there is no forcing in buying. The visitors from many different countries can freely take pictures, enjoying the awesome panaromic of the city. There are thousands of visitors come to this tourism attraction each day, either on the day or night. Until nowadays, there have been 700.000 Pairs of padlock stick in this bridge. ${ }^{7}$

Back to the problem of Siti Nurbaya Bridge, this interesting attraction surely has an opportunity and potency to keep being there and develop. If only it is agreed, night market could be specialized as an area of culinary of Minangkabau traditional food. So that there will be some offers for night markets in Padang, either for Pasar Raya which is already being accessible by the local society, Tarandam Market with its culinary sides, or Siti Nurbaya Bridge.

\section{A Collaboration of Culture and Tourism}

Events or festivals play important roles in increasing economic sides and developing its society (Wood and Thomas, 2009; Leaks, 2008). The observation of three events held in Wales, those are food, music and art festival proved that an event is absolutely could attract the attention of the visitors. And of course, in an event there has to be a concept of activities, resources, and actors (Elbe, 2009).

The planning to perform Randai as an attraction in Siti Nurbaya Bridge has to be done perfectly. Randai is considered to be able to attract the visitor's attention, not only the ones who come from Padang, but also the ones who are domestic or foreign visitors.

Randai is a traditional art of Minangkabau that compiles theater, matial art, traditional dances, and traditional music instrument. Randai is played in a group with a rounded formation, it is usually played by 14 to 25 players, and it doesn't need a special stage because it just needs an open space and doesn't limit the interaction with the spectators. Sometimes, the players involve the visitors joining in their dialogue.

Since long time ago till nowadays, Randai is not only presented as an entertainment, but also as a media to deliver messages and advices to the

7 http://www.paris.fr/accueil/actualites-municipales/des-rambardes-vitrees-experimentees-sur-le-pontdes-arts/rub_9656_actu_148320_port_23785

http://www.paris.fr/accueil/paris-mag/trop-lourd-I-amour-a-la-passerelle-des-arts/rub_9683_ actu_134240_port_23863 
society. Thus, Randai is not just a show, but it is really meaningful. ${ }^{\mathbf{8}}$ For more detail, Randai has three functions as a media of entertainment, education, and Minagkabau cultural preservation (Paulka, 2000).

The stories which are chosen are folktales of Minangkabau people with their intrigue, conflicts, debates, and romanticism. As time flows, the theme of its story develops but still contains original silek, dance, and music. In the beginning the players of Randai were all men, even though it should be acted by a woman, and he had to imitate the woman's voice, as to be called 'shemale'. Of course this action is a little bit contradictory with the philosophy of Minagkabau culture which based on Islam. But since 1960's, woman is allowed to be a player in Randai while there was established an academy with Randai as one of the subject (Paulka, 1996).

How to make the event of Randai success? United Kingdom as one of the biggest tourism destination countries in the world that has various tourists attractions, faced the declining the number of visitors on Visit Britain 2005. And how is the event of Randai? The visitors of Randai predicted that have a curiosity to amuse the Randai performance, learn Minangkabau culture, and get the leisure. Talking about profit, a leisure attraction offers shorter supply chain for the stackholder (Camp in Richards and Wilkes, 2008:41). In this case, the event of Randai has an objective to preserve the Minangkabau culture, not to renovate the traditional art value, nor commercialize as business industry.

According to the questioner distribution to the visitors, the results are as follows:

- Almost all visitors agree with the event of Randai.

- The frequency of Randai performance is quiet rare recently, creating the event is a moment to review and re-learn the Minangkabau art tradition, particularly for young ages.

- The event of Randai is audiovisual, it certainly attracts the visitors.

- Not only Randai but also Minangkabau traditional dances.

- The Government of Padang city should have seriously involved in managing the event, especially for the tourists comfortability. The access of transportation should be more various to reach this area.

- The tourists will get the knowledge from Randai performance.

Only small number disagrees with Randai, caused by technical factors. According to them, the event Randai will not be effective to be held in Siti Nurbaya Bridge, needs larger space. The amount people will more contribute the traffic jam.

Eventhough the cultural event and contemporer has been presented in

8 According to Mak Katik, an expert on Randai, argumented that,"the art of Minang is alive and develop, as well as interesting and being adored by worldwide, and it's all because the art has its own soul: so that it lives and gives a very deep impression for the visitors 
Taman Budaya (Cultural Park), which is located at the fornt of Padang beach, but it has different attraction. Also, the annual Siti Nurbaya Festival which is held by the government of Padang city can be an alternative to present in Siti Nurbaya Bridge.

By the expansion of tourist attraction in Siti Nurbaya Bridge into a culinary night market and Randai performance, thus considered to give additional value to the society, to involve the local people maintain the number of visitors, to participate in developing the attraction quality, to be aware of Minangkabau culture and to learn the guests' culture in a very good manner. Thus, the vendors would not manipulte the function of this bridge and appoint the visitors position anymore. But then, the trading process while in a tour should run very well, katuju di awak, sanang di urang. There should be trustworthiness between the host and the visitors. This is what we call as the concept of hospitality or "warm-hearted". According to the Dictionary, Tourism and Hospitality, hospitality is defined as 'the act or practice of being hospitable; the reception and entertainment of guests or strangers with liberality and goodwill'. It means that attitude and the way in welcoming the guests should be observed through lineament, facial expression, and the language, whereas they will determine the impression received by the visitors. A memory of a place, either it is good or bad; will last to the power of mouth in sharing to other people.

From the arguments above, the strength point is Siti Nurbaya Bridge allows the tourists to enjoy the panoramic of Batang Harau River and Padang Mountain also present the performance of staging art by the local people. The access for the vehicle started from the every edge of the mountain will be closed for a while, in order to let the visitors to walk and enjoy the views from the bridge. The arrangement of parking area needs to be done, so it will make everyone feels comfortable and reduce the pollution in the night. Transportation tools such as public transportation could be added to get into the location itself. The main road could be used as the arena of performance and food stands. Moreover, the sidewalks could be used to walk as it has to be.

\section{Conclusion}

Siti Nurbaya Bridge is considered not in an appropriate way to invite the tourists in bigger number, unless the ones who are originally from Padang. The existing of vendors who monopolize the bridge encouraged the limitation of tourists' accessibility and comfortability, just impede the motion of visitors, it evoques their short stay. As the concequences, the local people do not get the benefit in term of economy effectively. Richards and Wilkes (2008) said that there is no simple recipe exists to guarantee the successful development and operation of a visitor attraction, many factors and issues affecting the sector in the first decade of the twenty-first century. A strike is 
needed; creating an innovation such like the culinary night market and randai considered valorizing and preserving the culture value and attracting more tourists. The various objectives of tourists should be analyzed to identify the nature, role, and the innovation of the attraction (Leask, 2008).

Randai and night market which will be held in Siti Nurbaya Bridge are an effort to prepare cultural tourism that called by Picard (2006) as "good tourism", which maintains a harmony between tourists and local society as well as its surroundings, not as versa, gives disadvantages to one side and doesn't take care of the environment.

\section{References}

Budaya Melayu: Randai, Drama Tradisional Minangkabau. Retrieved from http:// melayuonline.com/

Dasrul. 2013. Komodifikasi Pertunjukan Randai pada Kelompok Seni Tradisi Palito Nyalo Kecamatan Pauh Kota Padang. Thesis Abstarct, 728

Destinasi di Indonesia. Randai: Menikmati Perpaduan antara Musik Tradisional, Cerita Rakyat, Drama, dan Silek Minangkabau. Retrieved from www. indonesia.travel/id

Dinas Kebudayaan dan Pariwisata Kota Padang. 2013. Profil Pariwisata Kota Padang. Padang

Elbe, Jorgen. 2009. A Model for Analysing the Development of Public Events. In Jane Ali-Knight (Eds), International Perspectives of festivals and Events: Paradigms of Analysis (pp. 227-239). London: Elsevier

ETC. 200o. Action for Attraction. Great Britain: British Council

Herwandi. (2014, October 5). Pisahkan Pengelolaan Dari Pariwisata: Sudah Saaatnya Mendirikan Dinas Kebudayaan. Retrived from http://www. mantagibaru.com/2014/10/pisahkan-pengelolaan-dari-pariwisata.html

Jamrah, Alfian. (2014, October 5). Pisahkan Pengelolaan Dari Pariwisata: Kebudayaan Urusan Wajib. Retrived from http://www.mantagibaru. com/2014/10/kebudayaan-urusan-wajib.html

Kementerian Pendidikan dan Kebudayaan. 2013. Rencana Induk Nasional Pembangunan Kebudayaan 2010 - 2025. Retrieved from http://kebudayaan. kemdikbud.go.id/wp-content/uploads/2013/12/Paparan-RIPNK-Komisi-3.pdf Leask, Anna. 2008. The Nature and Role of Visitor Attractions. In Fyall, Alan (Eds), Managing Visitors Attractions: New Directions (p.4-15). Oxford: ButterworthHeinemann

Medlik, S. 2003. Travel, Tourism \& Hospitality. 3nd ed. Burlington: ButterworthHeinemann

Pearce, Philip L. 2005. Tourist Behaviour: Themes and Conceptual Schemes. Great Britain: Cromwell Press.

Pauka, Kirstin. 1996. A Flower of Martial Arts: The Randai Folk Theatre of the Minangkabau in West Sumatra. Asian Theatre Journal, Vol.13, No.2 (autumn, 
1996), pp. 167-191

Pauka, Kirstin. 2000. Theater and Martial Arts in West Sumatra: Randai and Silek of the Minangkabau (Review by Richard, W Anderson). Asian Theatre Journal, Vol.59, No.2 (May, 2000), pp. 488-489

Peraturan Pemerintah Republik Indonesia Nomor 50 Tahun 2011 Tentang Rencana Induk Pembangunan Kepariwisataan Nasional Tahun 2010 - 2025. Retrieved from http://www.parekraf.go.id/userfiles/file/batangtubuh.pdf

Picard, Michel. 2006. Bali: Pariwisata Budaya, Budaya Pariwisata. (Couteau, Jean \& Wisatsana, Warih, Trans). Jakarta: KPG. (Original was published 1992)

Richards, G. (Ed). 2001. Cultural Attractions and European Tourism. Wallingford: Cabi Publishing

Richards, Steven., \& Wilkes, Keith. 2008. Attraction Failure ang Success. In Fyall, Alan (Eds), Managing Visitors Attractions: New Directions (p.4o-58). Oxford: Butterworth-Heinemann

Sudarmoko. (2014, Octobre 5). Pisahkan Pengelolaan Dari Pariwisata: Ubah Pemahaman tentang Kebudyaaan Terlebih Dahulu. Retrived from http:// www.mantagibaru.com/2014/10/pisahkan-pengelolaan-dari-pariwisata_5. html

Yurnaldi. (2003, August 29). Musra Dahrizal Katik Rajo Mangkuto: "Ruh" Seni Randai. Kompas. Retrieved from http://mantagisme.blogspot.fr

Wood, Emma. H., \& Thomas, Rhodri. 2009. Festivals and Tourism in Rural Economies. In Jane Ali-Knight (Eds), International Perspectives of festivals and Events: Paradigms of Analysis (pp. 149-158). London: Elsevier

\section{Writer Profile}

Deni Endriani was born on May, 15, 1982 in Cingkariang, Agam, West Sumatera. She graduated from Master Program of Double Degree in 2011 (Universitas Udayana IREST Universite Paris 1 Sorbon Pantheonne 2009-2011) majorin “ Gestion des Sites culturels et naturels et Valorisation Touristique ", Management of the Cultural and Natural Sites and Tourist Valorisation. At this moment, she is registered in second year of doctoral program in EHESS (École des hautes études en sciences sociales) Paris. Her research is about the Cultural Tourism in West Sumatera (Le tourisme cultural à Sumatra Ouest, le cas à Bukittinggi et à Padang) on sociology, anthropology, and political approaches. Since 2008, she teaches in Politeknik Negeri Padang as lecturer. She is eager to do research on tourism studies, cultural identity and ethnic, and museum studies. 